STUDIA UKRAINICA POSNANIENSIA, vol. II: 2014, pp. 135-145.

ISBN 978-83-936654-5-7. ISSN 2300-4754.

\title{
У ПОШУКАХ ВЛАСНОГО ЧАСОПРОСТОРУ. ХРОНОТОП ПОДОРОЖІ У ТВОРЧОСТІ УКРАЇНСЬКИХ І ПОЛЬСЬКИХ ПИСЬМЕННИЦЬ
}

\author{
МИРОСЛАВА КРУПКА \\ Рівненський державний гуманітарний університет, Рівне - Україна \\ W POSZUKIWANIU WŁASNEJ CZASOPRZESTRZENI. \\ CHRONOTOP PODRÓŹY W TWÓRCZOŚCI WSPÓŁCZESNYCH \\ PISAREK UKRAIŃSKICH I POLSKICH
}

\author{
MYROSLAVA KRUPKA \\ Rówieński Państwowy Humanitarny Uniwersytet, Równe - Ukraina
}

STRESZCZENIE. W artykule została podjęta analiza porównawcza powieści Badania terenowe nad ukraińskim seksem Oksany Zabuzhko oraz Bieguni Olgi Tokarczuk. Autorka analizuje motyw podróży, ujęty w kategoriach poszukiwań egzystencjalnych oraz zrealizowany poprzez koncepty języka, historii, ojczyzny, obywatelstwa, rodziny, a także domu. We wnioskach wskazano na podobieństwa w interpretacji podróży jako sposobu odnajdowania tożsamości we współczesnej literaturze ukraińskiej i polskiej.

\section{IN SEARCH OF INTIMATE SPACE AND TIME. \\ CHRONOTOP OF TRAVEL IN UKRAINIAN AND POLISH FEMALE WRITERS' WORKS}

\author{
MYROSLAVA KRUPKA \\ Rivne State Humanitarian University, Rivne - Ukraine
}

ABSTRACT. Comparative analysis of novels Field Work in Ukrainian Sex by Oxana Zabuzhko and Runners by Olga Tokarchuk is within the scope of the reseacher's interest in the article. The theme of a journey is in the centre of study; interpreted in the categories of existential search and revealed through the concepts of language, history, motherland, nation, family and home. The conclusion is related to the similarity of using of the image of a journey as a pattern of selfidentification in contemporary Ukrainian and Polish literature.

\footnotetext{
$\mathrm{C}$ учасне літературознавство тяжіє до осмислення просторових модифікацій художнього світу. Зокрема, цікавою видається версія жіночої літератури, оскільки традиційна культура приписувала жінку до сфери приватного, проте вона не мала особистої території як символічної можливості бути собою. У романах Польові дослідження з украӥнського сексу (1996) Оксани Забужко та Bieguni (2007) (Бігуни - 2011) Ольги Токарчук саме пошуки власного простору постають наскрізною проблемою і мають екзистенційні параметри: герої шукають насамперед самих себе.
} 
Творчість Ольги Токарчук висвітлювалася в Україні частково у рецензіях Наталки Малетич, Тетяни Дзядевич, Остапа Сливинського. Інтерпретація доробку Оксани Забужко здійснюється у дослідженнях Ніли Зборовської, Ольги Корабльової, Наталії Лебединцевої, Лариси Масенко, Наталії Монахової, Олени Юрчук.

Використовуючи просторовий фактор, Оксана Забужко у романі Польові дослідження з украӥнського сексу досягає ефекту „всюдиприсутності”. Н. Монахова зауважує, що дія роману ніколи не відбувається тільки в Україні або тільки за ії межами: складна граматична побудова речення дозволяє десятки разів перетинати кордон - і лишатися у межах одного речення, що розриває часові та площинні рамки, уможливлюючи свободу не просто на фізичному, а на мисленнєвому рівні ${ }^{1}$.

Побутова невлаштованість головної героїні роману у американських реаліях (кран протікає, відірвані дверцята шафок, таргани) лише віддзеркалює iii духовне сум'яття. Життєвий часопростір максимально звужується, сил вистачає триматися лише за сьогоднішній день. Гнітюча туга і безнадія ідеально співвідносяться 3 перехідністю та незакоріненістю тимчасового житла, „де бруди всіх попередніх винаймачів невідмивно повсякали в кожну шпарину, так що ти й не бралася їх відмити"2. Життя втрачає свою цінність і навіть вазони, покликані створювати затишок, реагують на депресивний стан і засихають при найретельнішому догляді, посилюючи сприйняття квартири як пустелі. Помешкання є символічною проекцією внутрішнього світу героїні, що перебуває у межовій ситуації між життям та смертю. Через символіку просторової пустки наголошується внутрішня порожнеча: побудова кухні передбачає обов'язкову присутність іншого, тобто утворюється функціональна безодня, що з дня в день поглинає єдину мешканку.

Внутрішня сутність людини у романі Оксани Забужко асоціюється з простором в'язниці, що відображає ситуацію несвободи. Крім того, героїня має проблеми $з$ множинною ідентифікацією - від лотри, котра знищувала коханого чоловіка, до маленької дівчинки, яку „від підлітка намагалася тримати в найглухішому підвальному закапелку, без хліба й води, щоб не поворухнулася"”, проте екзистенційний вияв іiі сутності зводиться саме до інфантильності. Саме через топос вокзалу поглиблюється настрій тимчасовості та невлаштованості, а також зраджується бажання притулку, роль якого у романі перебирає на себе мова. Вона виконує традиційну функцію дому: захисту, спокою, пов'язаності з рідною землею.

${ }^{1}$ Н. М о н а х о в а, Підпорядковане в украӥнському контексті (Спроба постколоніальної інтерпретації роману Оксани Забужко „Польові дослідження з украӥнського секcy”, [в:] „Сучасність” 2003, № 4, с. 138.

${ }^{2}$ О. 3 а б у ж к о, Польові дослідження з украӥнського сексу, Київ 2000, с. 11.

${ }^{3}$ Там само, с. 13. 
Мовна ідентифікація виявляється єдиною доступною для героїні, тому чужина сприймається насамперед як загроза на мовному рівні. Інша країна намагається інтегрувати у свій простір через англійську мову; подібно в Україні діє російська, що володіє потужною імперською наступальністю і асимілює свідомість.

Батьківщина постає через екзистенційне осмислення концептів чужини і рідного краю. У Автобіографії письменниця зазначала, що саме під час перебування в США перед нею відкрилася „нова оптика бачення власної країни та iii історії’4. Н. Лебединцева наголошує характерне для художнього світу О. Забужко протиставлення цивілізованого світу та української землі ${ }^{5}$. Закордон сприймається як перспектива реалізації життєвих намірів, натомість батьківщина - „Хронос, який хрумає своїх діток з ручками й ніжками”. Вирватись - стає світоглядною установкою і проявляється через конфлікт ідентичностей, що увиразнюється маскою Попелюшки. Героїня бачиться для світу особою, „що летить через океан понарікати за вечерею у Шеффілда 3 парочкою Нобелівських лауратів (промінячись навсібіч, чотирма мовами нараз за одним столиком сиплючи) на ідейну вичерпність сучасної цивілізації,”, в реальності іiі життєвий горизонт обмежується тісним простором маминої кухні. Перебування у батьківському домі позначене дискомфортом: донька займає там забагато місця, оскільки давно переросла цей рівень. Романтичне уподібнення матері та вітчизни оприявлює ще одну психологічну проблему, адже родинна опіка не дає можливості подорослішати. Тому у такій ситуації актуальним видається позбутися як географічної прив'язаності, так і психологічної залежності, яка непідвладна кордонам, але постає внутрішньою перепоною і не відпускає. Стверджуючи, що героїня бореться з колоніальним світом навколо себе й у собі, О.Юрчук зауважує, що комплекс неповноцінності спонукає іiі до пошуку самоідентифікації на чужій землі, адже „саме протиставлення з чимось дозволяє українцям вирізнитися"”. Ці дві просторові площини: подорож у координатах вітчизняної та особистої історії, визначають світоглядну перспективу персонажа.

Наскрізною проблемою твору є пошук дому. Через символіку дзеркала постає зустріч зі собою: „на тебе глянуло [...] виплигуюче назовні чорними очиськами личко, яке ти завжди за собою знала, але в дзеркалі не бачила вже хтозна-відколи: ти вернулась до себе, ти була вдома", і приходить усвідом-

${ }^{4}$ О. 3 а б у ж к о, Сестро, сестро, Київ 2004, с. 235.

${ }^{5}$ Н. Л е б е д и н ц е в а, Свропа як даність: Оксана Забужко versus Юрій Андрухович, [в:] Т. Г у н д о р о в а [ред.], Свропейська меланхолія. Дискурс украӥнського окииденталізму, Київ 2008, с. 90.

${ }^{6}$ О. 3 а б у ж к о, Польові дослідження..., зазнач. праця, с. 22.

${ }^{7}$ Там само, с. 29.

${ }^{8}$ О. Ю р ч у к, У тіні імперії: Українська література у світлі постколоніальної теорї, Київ 2013, с. 205.

${ }^{9}$ O. 3 а б у ж к о, Польові дослідження..., зазнач. праця, с. 26. 
лення справжності стосунків із чоловіком, який допоміг знайти втрачений дім, не як конкретний географічний топос, а як родинну атмосферу. Водночас саме через просторовий фактор письменниця передбачає приреченість любовного зв'язку: закохані розминалися в аеропортах, блудили біля свого дому, їх виштовхували пожежами тимчасові помешкання. Проте ці знаки героїня не відчитувала, засліплена несподіваним щастям зустрічі з достойним чоловіком, що набуває абсолютної цінності: „бо більше, ніж брат, бо вітчизна і дім [...]”10. Пошук іншого у романі Забужко постає як необхідність знайти собі подібного: „а то був перший мужчина з твого світу ...ти впізнала: свій, в усьому - свій, одної породи звірюки!" 11 . Попередній досвід особистих стосунків заклав стійкий комплекс неповноцінності і приреченості на поразку: чоловіки зображуються потворними як зовнішньо, так і внутрішньо. Любовні історії 3 чужинцями також виявляються дисгармонійними, адже у цьому випадку вони перестають бути лише відносинами двох, а уособлюють набагато більше - прірву ментальностей, матеріальних можливостей і життєвих установок. Увага чоловіка через матеріальні знаки провокує почуватися „типовою совковою проституткою, що трахається в готелі за пару трусів", 2 .

У романі „приреченість на вірність” трактується як життєве прокляття, адже героїня усвідомлює, що писати - це єдиний шанс підтримувати зв'язок із минулими поколіннями і почуватися причетною до народу, проте „український вибір - це вибір між небуттям і буттям, яке вбиває" ${ }^{13}$. Виразно протиставляється Україна і цивілізація через топос аеропорту-крематорію, що символізує неналежність до світу. Проте саме у подорожі Оксана доходить висновку, що людиною керує відчуття генетичного зв'язку з рідною землею - „я вернуся, я доповзу доздихувати, як поранений пес, залиганий повідком нікому не знаної мови" 14 . Життя на чужині в динаміці нових вражень та знайомств демонструє відкритість героїні і прагнення презентувати Україну в світі. Жадоба пізнання нового вирізняє іiі серед решти земляків, світоглядні простори яких обмежуються щоденною боротьбою за існування і навіть закордонні поїздки українці здійснюють винятково з практичною метою:

вона їхала колись у такому поїзді, з Києва до Варшави, на фестиваль поезії, здумати лишень! - хижа навала торбешників, плацкартний вагон, затарений бебехами попід стелю, - товар, ось як воно все у них звалося - [...] звично бридливий вираз на свіжопоголеній пичці польського митника, який бере - по пляшці водки від „пшедзялу”, i це ще харашо, запевняють помолоділі на радощах тітки, обтрушуючись і витягаючи - уфф, пронесло! - з бездонних спортивних рейтузів по дві-три чудесно врятовані пляшки, кожна потягне в Хелмі на десять баксів ${ }^{15}$.

\footnotetext{
${ }^{10}$ Там само, с. 110.

${ }^{11}$ Там само, с. 30.

12 Там само, с. 83 .

${ }^{13}$ Там само, с. 40.

14 Там само.

${ }^{15}$ Там само, с. 65-66.
} 
Чужина дає шанс розпочати все заново, проте відштовхує способом життя, який передбачає демонстраційну успішність. Вдавання набуває функцій щоденного ритуалу і приводить до проблематизації внутрішньої ідентифікації. У романі наскрізно підкреслюється емоційна лицемірність Америки: зовнішнім благополуччям прикривається драматична безвихідь реального життя (хвороби, алкоголізм, ностальгія). Це суспільство, в якому всі носять маски щасливих людей, диктує свої правила, і героїня приміряє чуже обличчя. Як дорогий одяг-подарунок коханця, зробив 3 неї журнальну модель, якою вона психологічно не була, так само і чужа ментальність лише каталізувала внутрішню дисгармонію.

Сучасний англійський філософ 3. Бауман, досліджуючи моделі свідомості постмодерного індивіда на основі просторового фактора, виокремлює типи фланера, бродяги, туриста і гравця ${ }^{16}$. Однак поведінка героїв сучасної української прози i, зокрема Оксани Забужко, відповідають саме типу модерної особистості, яку 3. Бауман класифікує як паломника зі життєвою стратегією побудови ідентичності, адже „про ідентичність згадують тоді, коли немає впевненості в своїй приналежності" ${ }^{17}$. Проте варто зазначити, що така ситуація свідомості характерна для літератури середнього покоління, - молодші митці бачать проблему більш глобально. Дослідниця Я. Шевчук, порівнюючи героя сучасної польської та української „молодої” прози, вживає термін „ескапізм", наголошуючи на втечі як його життєвій стратегії ${ }^{18}$.

У романі Польові дослідження з украӥнського сексу рух дає шанс зберегти життя і вирватись із лабет системи - ця істина засвоєна героїнею з дитинства, проте наслідком такої стратегії є відмова від сталості, а отже - i домівки. Травматичний досвід плюндрування дому, коли рушилося не лише домашне вогнище, а й знищувалося почуття життєвої захищеності, змоделював подальшу боязнь облаштовувати власний дім. Оксана розуміла, що у тогочасних умовах приватний простір не є запорукою надійності, і втікала, воліючи не переживати подібне. Дім, який гарантував безпеку, втратив свою функцію у країні „примусового щастя”: „коли зростаєш у квартирі, яка постійно прослуховується, і ти про це знаєш, так що вчишся говорити - одразу на невидиму публіку: де вголос, де на мигах, а де й змовчати"19. Зусібіч позбавлена приватності, героїня з насторогою ставилася до навколишніх, розцінюючи себе лише як засіб здобуття інформації. У такій ситуації сім'я втрачає статус захисту і провокує бажання відмежуватися від травмованого страхом батька та вічно втомленої матері. Родинна спадщина, що уподібнюється до каміння, трактується як трагічне переживання нереалізованості, що відкладається в па-

16 3. Б а у м а н, От паломника к туристу, [в:] „Социологический журнал” 1995, № 4, c. 142 .

${ }^{17}$ Там само, с. 134.

18 Я. Ш е в ч у к, Ното ехсаррапs: герой сучасної польської та украӥнської „молодоі” прози, Житомир 2012, с. 219.

${ }^{19}$ О. 3 а б у ж к о, Польові дослідження..., зазнач. праця, с. 82. 
м'яті з покоління в покоління. (Розуміння цього стане лейтмотивом найновішого роману Оксани Забужко Музей покинутих секретів - 2009). Спадковий досвід символічно бачився домовиною. Генетична пам'ять підказувала єдиний спосіб не повторити життєву модель попередників - вирватися. Лише рух провокує зміни і дає шанс переінакшити не тільки свою долю, але й перервати трагічний ланцюг родової приреченості на небуття.

Саме через просторовий фактор героїня усвідомлює себе. Місто, де вона знайшла кохання, - це місто ії дитинства. Вона ніби повертається на 25 років назад і має шанс почати все заново: „там завмирає дівчинка серед осінньої алеї, вперше зачувши, як стугонить за туманом далекий обрій, як світ кличе іiі, обіцяючи їй дорогу, от з тої дівчинки все й починається, i що б не було потім 3 тобою в житті, - цільне, держиться при купі доти, доки ти віриш тій дівчинці, доки вловлюєш у собі почутий тоді нею поклик"20. Спогади про дитинство постають як спосіб віднайдення ідентичності. До неї приходить розуміння зашифрованих знаків, що виринають у віршах та снах через відтінки запаху та світлові нюанси. Оксана Забужко описує символічне життєве коло героїні: місто дитинства, дім, з якого вирушила в дорогу, рідні місця знову актуалізуються у свідомості через зустріч із чоловіком, що чекав на неї весь цей час.

Досвід чужої країни спонукає знаходити різноманітні способи утвердження себе у світі, вибудовувати модель поведінки і відкривати альтернативні сенси буття: „і тоді вона розуміє, що кайфувати од себе, по-щенячому тішитись кожною ознакою власної присутности в світі, - це так само один із способів витворювати в ньому дім"21. У фінальній сцені у літаку, коли героїня повертається на батьківщину і пізнає себе у п'ятирічній дівчинці, вперше звучать оптимістичні ноти, оскільки до неї приходить усвідомлення себе справжньої.

Подібне розуміння руху як сенсу життя прочитується у романі Ольги Токарчук Бігуни, де в калейдоскопі миттєвих вражень і мозаїчних подій постає історія сучасності, коли простір і час втрачають споконвічну усталеність і перетворюються в мінливість. Дійовими особами книги є люди різних національностей, але всіх їх об'єднує розуміння життя як подорожі. У такій ситуації поняття дому замінюється візією тимчасовості, адже повернувшись, героїня все ще перебуває у координатах мандрівки, оцінюючи і власне помешкання за готельними критеріями. Житло втрачає свою цінність, його заступають летовища, що творять власний світ. Самоідентифікація також відбувається через сприйняття рідного дому: ій байдуже, де вона перебуває, натомість головним постає усвідомлення, що вона існує. Богдана Криса виводить мотив мандрів як відречення від сталих форм і явищ 3 традиції життєвих мандрів, блукань у тимчасовому земному світі, стратегії паломництва ${ }^{22}$. У слушності

${ }^{20}$ Там само, с. 56.

${ }^{21}$ Там само, с. 52.

${ }^{22}$ Б. К р и с а, Пересотворення світу. Українська поезія XVI-XVIII століть, Львів 1997, c. 20. 
такого трактування переконує сама авторка Бігунів, яка у одному з інтерв'ю зізнається, що назву романові дала давня релігійна секта старовірців, яка існувала ще у XVIII столітті. Вони вірять, що зло закорінене у знерухомлені, тому щоб уникнути влади диявола, потрібно весь час перебувати у русі: „уже зраділа, що натрапила на цю метафору, бо вона мала виявляти незгоду зі світом, який пробує нас обмежити посадами, працею, грошима, рамками, документами, візами, паспортами тощо "23. О. Сливинський, досліджуючи тему подорожі у романах Ольги Токарчук, зауважує, що усі найважливіші сюжетні лінії будуються довкола події виходу, втечі із прогнозованого світу, відчалювання у безвість ${ }^{24}$.

Наскрізно у романі Бігуни звучить тема батьківщини. Героїня прагне залишитися анонімною, тому навіть зустрічаючи в аеропортах земляків і впізнаючи рідну мову, вибирає позицію стороннього спостерігача. Показовим $\epsilon$ епізод „в одній далекій країні”, де на лайку польською мовою відгукнулася випадкова людина, що на чужині забула все пов'язане з Польщею, проте постійно відчуває внутрішній дискомфорт від розлуки з рідною землею. I ця роздвоєність стає трагедією всього життя: „Мені важко повірити, що можна забути мову, якою були написані перші в житті мапи світу. Певно, вона іiі просто десь заховала" 25 . Мова виявляє свою об'єднуючу силу навіть тоді, коли у подорожах героїня зустрічає випадкові написи рідною мовою і несвідомо проявляє цікавість до долі саме цієї людини, тобто виокремлює іiі серед суцільного потоку інших, адже мандрівний стиль життя придає людським стосункам фрагментарність і тому повсякчас наголошується дистанція між собою та іншим.

Центральною темою творчості Ольги Токарчук є окреслення картини життя сучасної людини, як особистості нестабільної і мобільної, що презентує нову генерацію, позбавлену прив'язаності до землі: „і перший-ліпший подмух вітерцю вириває мене з грунту. Моя енергія виникає з руху - 3 похиту-

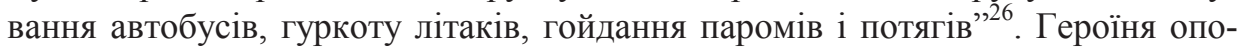
віді має ідеальні параметри для мандрівки: і фізичні, і психічні. Юлія Крістева так акцентує гендерну особливість подорожуючих:

всупереч традиційним поглядам, мандрівниця не шукає ніякого хатнього вогнища, ніякої рідної землі, ніякого родинного притулку [...] Хитрощі мандрівниці [...] полягають у тому, щоб не мати „дому”, розглядати кожен „дім” як місце [...] Іншого 27.

${ }^{23}$ Ольга Токарчук: „Дедалі менше людей вірить у безсмертя душі...”, [електронний pecypc:] http://ratusha.lviv.ua/oljga_tokarchuk.html

${ }^{24}$ Творчість Ольги Токарчук: кілька крапок над „i”, (ч. I), [електронний ресурс:] http://litakcent.com (2009.09.28).

${ }^{25}$ О. Т о к а р ч у к, Бігуни, переклад з польської О. Сливинського, Харків 2011, с. 331.

26 Там само, с. 8.

${ }^{27}$ Ю. К р і с т е в а, Полілог, переклад з французької П. Таращука, Київ 2004, с. 435. 
Сучасна героїня протиставляється поколінню батьків, що вели пересічне життя, яке уже новій генерації видається екстравагантним: „те дивне життя, коли вранці повертаєшся до того, що покинув звечора, коли одяг просякає запахом власного помешкання, а ноги невтомно витоптують стежину на килимі, 28 . Письменниця перевертає уявлення про традиційну життєву модель. 3. Бауман 3 цього приводу зауважує, що стилі, які колись вели маргінали на узбічних хронотопах, тепер практикує більшість в основний час свого життя і в місцях, розташованих в центрі життєвого світу ${ }^{29}$. Донька іронізує з батьків, для яких сенсом життя була домівка, натомість сама обирає рух. Відповідно формуються життєві пріоритети, адже ціниться лише те, що не ускладнює подорож, i навіть праця розглядається як засіб здобуття коштів на продовження мандрівки. Н. Малетич стверджує, що в романі порушується проблема втрати коріння, але не лише в політичному плані, а й у плані внутрішнього викорінення ${ }^{30}$.

У романі Бігуни оповідається про різних людей і сенс їхніх мандрівок: пошук родового коріння, втеча від реальності, проте інколи виникає нагальна необхідність „вийти 3 власного життя, згодом безпечно вернутися”з1. Через зміну географічного ландшафту вони намагаються позбутися тягаря повсякдення, не $\epsilon$ винятком і зразкові господарки, світ яких обмежується простором домашнього вогнища і необхідністю піклуватися про інших у замкненому колі родини. О.Токарчук зводить їхні подорожі до пізнання цілого світу через його мініпроекцію, замкнену „у маленькій бляшанці”. Можливість розширювати географічний простір бачиться як винагорода: „і дозволити зазирати туди лише в суботу пополудні, коли всі щоденні справи вже зроблені,

Подібне співвідношення жінки і світу прочитується в історії, яка дала назву цілому роману, - Бігуни. Письменниця локалізує події до Москви, де мешкає головна героїня, хоча реально вона ув'язнена в чотирьох стінах маленької квартири з невиліковно хворою дитиною та чоловіком-імпотентом. Замкнений простір помешкання наповнений негативною семантикою, оскільки Аннушка живе з хронічним відчуттям провини і демонструє підпорядкованість сімейним правилам. Дім у романі Токарчук уподібнюється до в'язниці і провокує бажання втечі. Життя жінки асоціюється з наповненою страхами та темрявою ніччю, адже саме „ніч повертає світові його первісний, природний вигляд, нічого не фантазує. День - то екстравагантність, а світло - дрібний виняток, недогляд, порушення ладу. Світ насправді темний, майже чорний. Нерухомий і холодний ${ }^{33}$. Проте навіть вранці сон не минає і життя прочи-

${ }^{28}$ О. Т о к а р ч у к, Бігуни, зазнач. праця, с. 7.

29 3. Б а у м а н, зазнач. праця, с. 142.

${ }^{30}$ Н. М а л е т и ч, Ювілейне прочитання Ольги Токарчук, [електронний ресурс:] http://zaxid.net/home (2012.02.20).

${ }^{31}$ О. Т о к а р ч у к, Бігуни, зазнач. праця, с. 63.

32 Там само, с. 59.

${ }^{33}$ Там само, с. 237. 
тується як продовження нічного жахіття. Лише один день в тиждень Аннушка має вихідний, що дозволяє ій подорожувати у безмежному просторі міста, яке у сприйнятті героїні перетворюється на пекельну безодню, що пожирає людські тіла: „безодня - всюди, навіть на одинадцятих і сімнадцятих поверхах хмародерів, на вершечках телевеж, на кінчиках антен. Від неї не втечеш” ${ }^{\text {”34 }}$ (У цій історії тісно переплітаються два основні мотиви роману - мандрівка по світу і подорож людським тілом). Хоча події твору охоплюють багато місць і навіть континентів, проте у сучасному світі саме Москва $€$ втіленням космополітичного мегаполіса. Авторка зображує столицю як монстра, що керує людьми через брак місця та руху: нескінченний потік людей, що не переривається ні вдень, ні вночі; нерухомі дороги, вщент забиті автомобілями; метро, що поглинає людей і вершить Страшний суд. Кожен житель мегаполіса ходить по певній траєкторії, яка символічно постає через образ ниточки, що веде додому. Т. Дзядевич так розмірковує над проблемою множинності ідентичностей у творчості О. Токарчук.

Хоча найбільш наочним маркером ідентичності у текстах письменниці є постійний i, можна сказати, наполегливий хронотоп дороги. Власне, крізь дорогу, мандрівку, крізь перетин/порушення/усунення кордонів/меж/рамок і конструюється поліфонія ідентичностей у текстах письменниці ${ }^{35}$,

- підсумовує вона.

Невеличка церква, наповнена старовинними іконами, виявляється єдиним простором належним людині. Саме сюди щотижня через людське море пробирається героїня, щоб знайти собі місце для ритуального плачу, що очищає іiї від болю і надає сили прожити чергову седмицю. Ціллю подорожі $є$ пошук гармонійного простору,

де мусить учуватися присутність когось, хто більший за неї, великих розпростертих обіймів, що тремтять життям. Аннушка мусить відчувати на собі чийсь погляд, відчувати, що ії плач бачить хоча б хтось, що вона не говорить у пустку ${ }^{36}$.

Образ Христа відіграє у цьому творі символічну роль того, до кого звернені слова. У романі Оксани Забужко - це уявна публіка, для якої прочитана лекція. Люсі Ірігерей з цього приводу зазначає, що для жінок факт висловлювання вголос своїх страждань $є$ моментом істини:

Подолати себе, висловити публічно індивідуальні та колективні біди - вже це дає терапевтичний ефект, вивільняє тіло і дає можливість розпочати новий відлік часу ${ }^{37}$.

${ }^{34}$ Там само, с. 245.

${ }^{35}$ Творчість Ольги Токарчук: кілька крапок над „і”, (ч. II), [електронний ресурс:] http://litakcent.com (2009.10.01).

${ }^{36}$ О. Т о к а р ч у к, Бігуни, зазнач. праця, с. 242.

37 Л. И р и г а р э, Как нам создать свою красоту? [в:] Л. Б р е д и х и н а (ред.), Гендерная теория и искусство. Антология: 1970-2000, Москва 2005, с. 418. 
Гранична одинокість жінки унікальна тим, що вона страждає від неможливості усамітнитися ні у власному домі, ні на вулиці. Цього разу вона навіть у церкві не змогла побути наодинці, оскільки люди витіснили іiї з особистого сакрального простору, що призвело до психологічної дезорієнтації, адже катарсису не відбулося і героїня відчуває, що у цьому світі навіть Бог загубив свою силу. Втрачений шанс через молитву позбутися тягаря щоденних випробувань змусив зійти з ритуального маршруту. Знайомство з бігункою відкриває перед нею іншу реальність - життя, яке протікає поза домом і перебуває у постійному русі: вокзали, метро, цілодобові кав'ярні, привокзальні кіоски і т.п. Хворобливі екзистенційні пошуки героїні постають через просторову парадигму.

Раптово Аннушка усвідомлює, що не може повернутися додому, тому приміряє маску бездомної і перетворюється на біженку із родини. Поняття дому також проблематизується, адже героїня позбавлена навіть дитячої родинної захищеності, яку відчувала Оксана із роману Польові дослідження з українського сексу. Простір дитинства Аннушки - це Воркута, де люди страждають хворобою смутку. Авторка зазначає, що жити там - „це наче висіти під бетонним склепінням світу всередині замерзлої краплини води, посеред холодного пекла" ${ }^{38}$. Відчуття пекла Аннушка переносить за собою і в інший простір - багатолюддя Москви і фокусує в квартирі з чіткою локалізацією - Кузнецька сорок шість, квартира сімдесят вісім. Керована прагненням вирватися, вона опиняється у маргінальному світі безхатченків. I саме у їхньому колі, на цементній підлозі напівзруйнованої котельні, жінка знаходить втрачений спокій і вперше за багато років, визволившись від непосильного тягаря відповідальності, міцно засинає і бачить безжурний дитячий сон. Він постає як фрагмент ритуалу долучення до спільноти бігунів, які перетворили рух на саме життя. Водночас топос дороги, яка нікуди не веде, оприявнює екзистенційну ситуацію блукання по колу. Нестримне переміщення у просторі виступає символічним вираженням незакоріненості буття.

Саме у нескінченних мандрах метро, залишаючись анонімною, Аннушка почувалася вільною і належною винятково собі. Вона обирає роль стороннього спостерігача і сприймає оточуючих як своїх союзників, що віддаляють ії від дому. Світовідчуття наповнюється ілюзією втечі із екзистенційної пастки. Однак цей стан удаваного щастя насправді лише тимчасова мандрівка у пошуку себе. Врешті у жінки переважає прив'язаність до дитини, від якої, виявляється, втекти неможливо, оскільки присутність сина відчувається у материнському тілі повсякчас: „Лежить там, скорчившись, важкий, як камінь, болісний. Набрякає в ній, росте; певно, їй треба народити його ще раз, тепер уже крізь шкіру, крізь усі пори, наче піт" ${ }^{39}$. Материнство прирікає жінку бути прив'язаною до домашнього простору, але у романі це відкриття постає як

\footnotetext{
${ }^{38}$ О. Т о к а р ч у к, Бігуни, зазнач. праця, с. 249.

${ }^{39}$ Там само, с. 258.
} 
своєрідна ситуація пробудження. Після блукань Аннушка повертається до себе і з деякою приреченістю усвідомлює, що жінка існує для самозречення, адже її ідентичність - материнство, яке чітко окреслює простір буття - там, де твоя дитина. Постать росіянки доповнює галерею героїв роману різних національностей і втілює ідею універсальності людського досвіду загалом, і жіночого, зокрема. Ольга Токарчук показує, що у світі, де йде процес нівеляції політичних кордонів, завжди залишаються внутрішні межі, які людина нездатна переступити, тобто констатується неможливість втекти від свого внутрішнього ,я".

У романах Польові дослідження з украӥнського сексу Оксани Забужко та Бігуни Ольги Токарчук простежується подібність способів художнього осмислення процесу самоідентифікації, який співпадає з подорожами, що здійснюють персонажі. Просторова парадигма увиразнює шляхи віднаходження власного „я”. У Оксани Забужко перебування поза межами батьківщини дозволяе героїні усвідомити свою особисту та громадянську місію. У романі Бігуни моделюються нові типи людських стосунків, проте також наголошується, що, попри стирання зовнішніх кордонів, втеча від свого призначення приречена на поразку. 